\title{
Metodologia de avaliação ambiental na análise de alternativas locacionais de pilhas de estéril
}

Environmental assessment methodology in the analysis of location alternatives for waste rock dumps

Ray Garcia Forgearini'1, Raul Oliveira Neto², Luis Eduardo de Souza², Luciana Arnt Abichequer², Ítalo Gomes Gonçalves ${ }^{2}$

${ }^{1}$ Tecnólogo em Mineração, Universidade Federal do Pampa, Caçapava do Sul,RS, Brasil

${ }^{2}$ Engenheiro(a) de Minas/Professor do Programa de Pós-Graduação em Tecnologia Mineral (PPGTM), Universidade Federal do Pampa, Caçapava do Sul, RS, Brasil

\section{Resumo}

Este trabalho visa aplicar uma metodologia de planejamento ambiental como auxilio à analise de alternativas locacionais para a disposição do estéril a ser gerado nas fases de desenvolvimento e operação da futura cava da mina Três Estradas de fosfato. Aplicando orientações técnicas, presentes na NBR 13029 da ABNT, com caráter de minimização dos impactos ao meio ambiente, aplicando pesos a parâmetros ambientais para cada alternativa e, assim, comparando-as e apresentando uma hierarquização das alternativas, o estudo leva a proposição de medidas mitigadoras e compensatórias gerais, que devem ser aprofundadas após a escolha da melhor alternativa por parte da empresa. Após aplicação da metodologia proposta no trabalho, chegou-se à conclusão, por uma das alternativas que foi melhor pontuada, de acordo com os critérios estabelecidos, que foi a Pilha 4, entre as quatro alternativas previstas no projeto.

Palavras-chave: pilha de estéril, impacto ambiental, medidas mitigadoras e compensatórias.

\begin{abstract}
This work use an environmental planning methodology, as an aid to the analysis of location alternatives for disposal of overburden to be generated during the development and operation phases of the future of pit mine phosphate Três Estradas. Applying technical guidance, present in the NBR 13029 of ABNT, with minimum character of the impacts on the environment by applying weights to environmental parameters for each alternative, and comparing them and introducing a hierarchy of alternatives, the study takes to the general mitigation and compensation measures proposition, which should be deepened after choosing the best alternative for the company. After this application of the proposed methodology at work, we came to the conclusion for one of the alternatives that was better punctuated, according to the established criteria, which was a stack 4 between the four alternatives set out in the project.
\end{abstract}

Keywords: waste dump, environmental impact, mitigating and compensatory measures. 


\section{Introdução}

É inevitável, na extração de bens minerais, a geração de uma quantidade expressiva de materiais de pouco ou nenhum valor econômico como rejeitos e estéreis. A remoção do estéril de uma área de lavra e a sua disposição final são responsáveis por grande parte dos custos de desenvolvimento de uma mina, com implicações não só econômicas, mas também no que se refere ao meio ambiente, envolvendo impactos significativos.

Com relação ao meio ambiente, há atualmente uma crescente conscientização da sociedade, que consequentemente passou a exigir mais dos poderes públicos e privados, ou seja, uma mudança no modelo de desenvolvimento sustentável que possa ser compatível com o crescimento econômico e sem destruição da natureza. Essa cobrança também é notada por parte dos investidores estrangeiros e compradores dos nossos minérios, que por terem base em países mais desenvolvidos e com maior cultura de preservação ambiental, buscam essa consciência por parte de nossas empresas.

Neste contexto é necessário que um projeto de pilha de estéril seja executado de maneira adequada, atendendo à empresa de mineração e aos requisitos básicos definidos pelas normas de segurança e proteção ambiental.

É correto afirmar, então, que um comprometimento com a qualidade dos recursos ambientais demanda, necessariamente, a incorporação de novos valores por parte das empresas e dos administradores públicos, a fim de que se alcance um nível mais elevado e equilibrado de desenvolvimento (Montaño et al, 2002).

A escassez de áreas adequadas para disposição de estéril torna inevitável a realização de um plano bem elaborado de manejo do mesmo. No Brasil, o projeto e o planejamento de uma pilha de estéril estão sujeitos a aprovações legais, como as normas de disposição de estéril, rejeito e produtos das NRM - Normas Reguladoras de Mineração do DNPM - Departamento Nacional da Produção Mineral e a NBR 13029 da ABNT que especificam requisitos mínimos para elaboração e apresentação de projeto para disposição de estéril.

O objetivo geral deste trabalho é a realização da análise da localização prevista das pilhas de estéril do projeto da mina de fosfato de Lavras do Sul, no contexto da gestão ambiental. Os objetivos específicos são a identificação e avaliação de critérios técnicos e ambientais de acordo com as normas legais (DNPM e ABNT), criando uma metodologia de hierarquização das alternativas através da atribuição de pesos ou níveis de adequação dos critérios. Identificando o melhor lugar para a instalação da pilha de estéril, otimizando o projeto e o planejamento, ainda como definir medidas mitigadoras, compensatórias e de recuperação, para prevenir impactos ambientais à alternativa escolhida.

O trabalho foi realizado com base no projeto de explotação de fosfato, localizado na borda Oeste do Escudo sul rio-grandense, no município de Lavras do Sul (Figura 1), onde a mineralização consiste de um corpo intrusivo de Meta Carbonatito do Proterozóico. A área se localiza no Bioma Pampa, com planícies de ondulações médias e vegetação rasteira, de gramíneas e leguminosas, e também se destina atualmente ao setor agropecuário, o que facilita o seu planejamento ambiental, reduzindo significadamente os impactos associados às operações do projeto. 


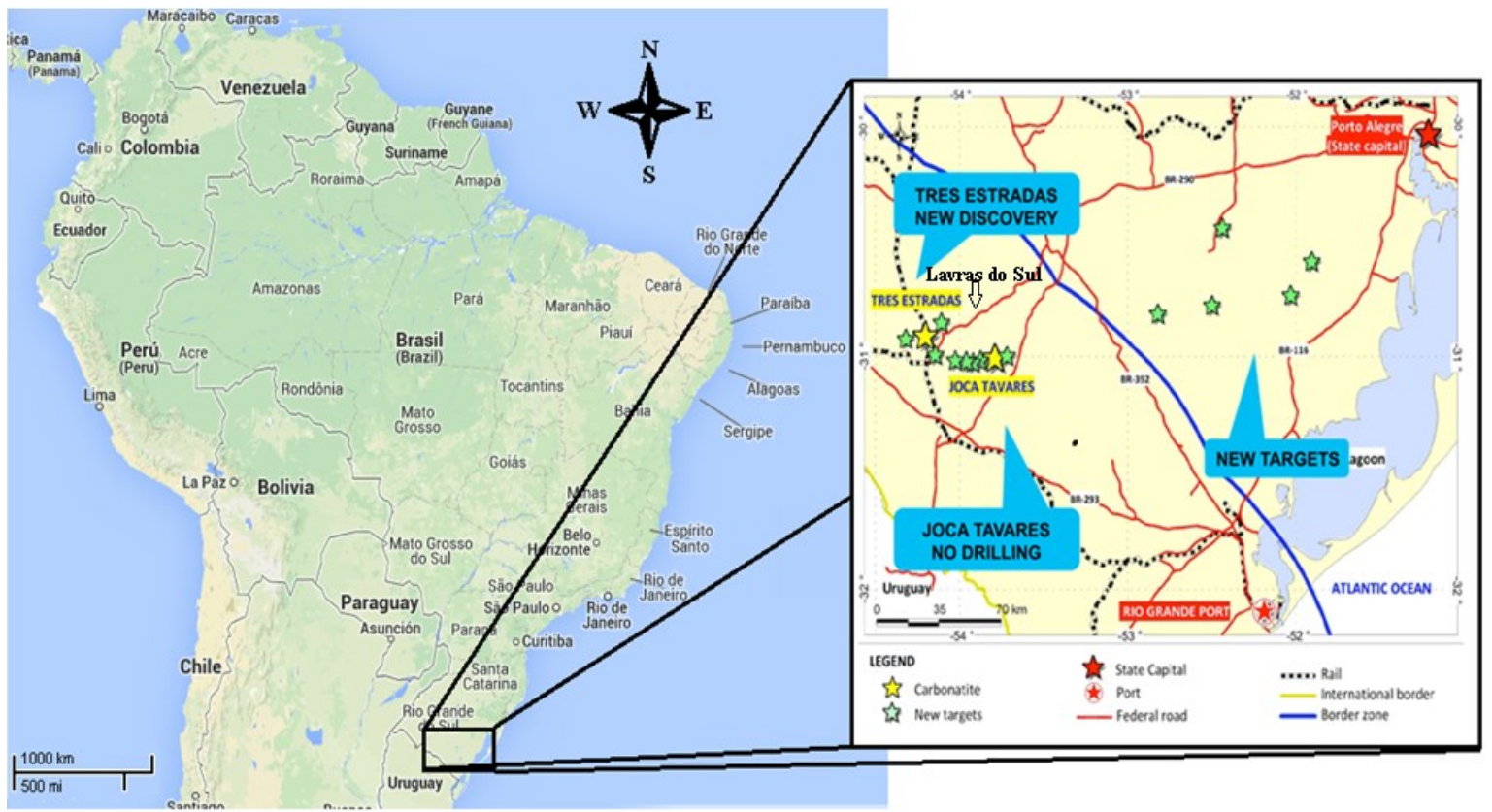

Figura 1: Localização e situação do Fosfato Três Estradas, Lavras do Sul/RS (fonte: Águia Resources, Volume II - Estudos Geotécnicos e Hidrogeológicos).

\section{Estado da arte}

\subsection{Pilha de estéril}

Estéril é um aglomerado de minerais sem ou com baixo valor econômico, retirado da área de lavra para garantir acesso ao corpo do minério a ser explotado. O material estéril deve ser identificado, removido, transportado e estocado. A estocagem geralmente ocorre sob a forma de pilhas, que podem ser desenvolvidas por dois métodos, os ascendentes (de baixo para cima), ou os descendentes (de cima para baixo que são os métodos de ponta de aterro).

Pelo fato das pilhas de estéril serem constituídas de diversos tipos de materiais, é importante que se tome o devido cuidado com as características dos mesmos, tais como: coesão, ângulo de atrito, peso especifico e ângulo natural de estabilidade dos materiais que englobam o estéril como um todo.

Alguns aspectos relevantes e orientativos a este trabalho, com respeito à de construção de pilhas de estéril são descritas na NRM 19 do DNPM e estão apresentados a seguir:

- a construção de depósitos de estéril, rejeitos e produtos deve ser precedida de estudos geotécnicos, hidrológicos e hidrogeológicos;

- os depósitos de estéril devem ser construídos com dispositivos de drenagem interna de forma que não permitam a saturação do maciço;

- a estocagem definitiva ou temporária de estéril e materiais diversos provenientes da mineração deve ser realizada com o máximo de segurança e o mínimo de impacto no ambiente.

A NBR 13029/1993 assim como a sua versão atualizada da ABNT - Associação Brasileira de Normas Técnicas que fala sobre a disposição de estéril em pilhas na mineração, deixa claro os melhores lugares para a disposição do material estéril, como dentro da própria cava da mina, ou o mais próximo possível, de preferência em áreas já degradadas e dentro dos limites legais do empreendimento. 
Como lugares menos apropriados citam-se: vales com talvegues de inclinação superior a $18^{\circ}$, drenagens, nascentes e cursos de água, áreas de preservação permanente, terrenos instáveis, alagadiços e sujeitos a inundações, área com vegetação nativa exuberante e solos férteis. Portanto, todos esses fatores e boas práticas devem ser levados em consideração no planejamento das pilhas de estéril, para evitar ou reduzir os impactos ambientais gerados pelas pilhas.

\subsection{Impacto ambiental}

A norma ISO 14.001 define impacto ambiental como qualquer modificação do meio ambiente, adversa ou benéfica, que resulte, no todo ou em parte, das atividades, produtos ou serviços de uma organização. Em pilhas de estéril podem ser identificados alguns impactos como erosão, carreamento de sólidos, ruptura de taludes, poluição das águas superficiais e subterrâneas, poluição visual, impactos sobre a fauna e a flora.

A identificação de impactos ambientais é uma tarefa que deve ser executada de maneira cuidadosa e sistemática, para assim abranger todas as alterações ambientais possíveis decorrentes do empreendimento. $\mathrm{O}$ entendimento das atividades e operações que compõem o projeto, e de suas alternativas, ao lado do reconhecimento das características básicas do ambiente potencialmente afetado, são os pontos de partida para a identificação preliminar dos impactos prováveis (Sánchez, 2008).

Os efeitos ambientais observados ou medidos em casos de empreendimentos semelhantes fornecem uma primeira pista para identificar os possíveis impactos de um novo projeto (Sánchez, 2008). Esse conceito é importante para podermos associar o planejamento das pilhas de estéril, com as possíveis alterações que ocorrerão ao meio ambiente, decorrentes dessa operação, fazendo uma ampla pesquisa, formando a base de conhecimento para uma boa identificação de impactos. Todos os lugares prováveis para a disposição dos estéreis do projeto devem ter os seus impactos identificados separadamente, com minucia de detalhes para que todos os impactos prováveis sejam incluídos sem distinção.

O passo seguinte, após a identificação dos impactos ambientais, é a avaliação dos mesmos. Uma avaliação de impacto ambiental de uma atividade visa identificar, prever, interpretar e comunicar informações sobre as consequências de uma determinada ação sobre a saúde e o bem-estar humanos (Sánchez apud Munn, 1975).

A avaliação dos impactos ambientais é importante no projeto de pilhas de estéril, para que depois dos impactos identificados, os mesmos sejam listados e classificados pela sua magnitude, e pelo tempo em que eles ocorrerão a curto, médio ou longo prazo. Essa listagem de classificação dos impactos é realizada para todos os locais que poderão ser utilizados para a disposição do estéril do projeto, auxiliando assim na escolha do melhor lugar para localização da(s) pilha(s). Outro importante objetivo da avaliação de impactos é a hierarquização dos mesmos, ou seja, pontua os mais relevantes e urgentes no sentido de implantação das medidas mitigadoras e compensatórias e de recuperação.

\subsection{Sistema de gestão ambiental}

Considera-se gestão ambiental como todo o esforço, estruturado e sistemático, incorporado à estrutura organizacional da corporação, com o fim de conhecer, prever e abrandar os impactos ambientais gerados em consequência da operação, produtos e serviços da mesma. Segundo a Sánchez (2008), o Sistema Gestão Ambiental - SGA é a parte do Sistema de Gestão Global que inclui a estrutura organizacional, o planejamento de atividades, responsabilidades práticas, procedimentos, processos e recursos para o desenvolvimento, implantação, alcance, revisão e manutenção de política ambiental.

Podemos dizer que a gestão ambiental engloba a política ambiental, o planejamento ambiental e o gerenciamento ambiental, integrando sempre esses elementos. Dentro da gestão ambiental, portanto, se encontra o planejamento ambiental, que visa solucionar os conflitos que possam ocorrer entre as 
metas de conservação ambiental e do planejamento tecnológico, englobando os conceitos de sustentabilidade e multidisciplinaridade.

Segundo Santos (2004), o planejamento ambiental tem como estratégia estabelecer ações dentro de contextos e não isoladamente, para assim apresentar um melhor aproveitamento do espaço físico e dos recursos naturais com economia de energia, alocação e priorização de recursos para as necessidades mais prementes identificadas.

\section{Estudo de caso}

\subsection{Descrição da área em estudo}

A área em questão esta situada no Bioma Pampa, na porção sul/sudoeste do estado do Rio Grande do Sul. Esta localização lhe dá características próprias, onde a vegetação é basicamente rasteira, e as áreas se destinam à agricultura e à pecuária em sua grande maioria. Geralmente essas áreas do Pampa Gaúcho, são divididas em propriedades com sedes de estâncias, fazendas e outras propriedades menores apresentando edificações dispersas. $\mathrm{Na}$ área do projeto, se encontram cerca de vinte e uma propriedades rurais, sendo que na porção nordeste da área encontra-se uma ferrovia, que cruza a mesma de norte para leste.

Como a característica da área é de médias propriedades rurais, não se encontram aglomerados urbanos, o que minimiza o impacto antrópico das pilhas de estéril. Pela distância de centros urbanos, não há coleta de lixo, acesso a transporte público, e tampouco fornecimento de água tratada.

A seguir são apresentadas algumas premissas básicas do projeto de extração do Metacarbonatito Três Estradas:

- reserva mineral total a ser lavrada: 40.000 .000 toneladas;

- volume total de rejeito: $20.000 .000 \mathrm{~m}^{3}$;

- volume total de estéril: $30.000 .000 \mathrm{~m}^{3}$;

- profundidade máxima da cava: $100 \mathrm{~m}$;

- estéril sem potencial para geração de drenagem ácida.

\subsubsection{Geologia da área}

A área em estudo está inserida no Complexo Granulítico Santa Maria Chico (Figura 2), onde as rochas deste complexo constituem a unidade estratigráfica mais antiga da região, com idade metamórfica de 2100 Ma. Este complexo granulítico é formado por gnaisses quartzo-feldspáticos (tonalitos e trondjemitos), gnaisses máficos, anortositos, ultramafitos e por rochas supracrustais metamorfisadas em condições de fácies granulito (Iglesias, 2000).

Os tipos litológicos predominantes na área são os gnaisses quartzo-feldspáticos, essencialmente granoblásticos, formados por plagioclásio, quartzo, muito pouco ou nenhum feldspato alcalino (ortoclásio ou microclínio), hiperstênio, diopsídio e hornblenda. Os gnaisses básicos são semelhantes aos quartzo-feldspáticos, mas contêm menos ou nenhum quartzo, mais plagioclásios e minerais máficos, localmente prevalece a presença dos anortosíticos (Iglesias, 2000). 


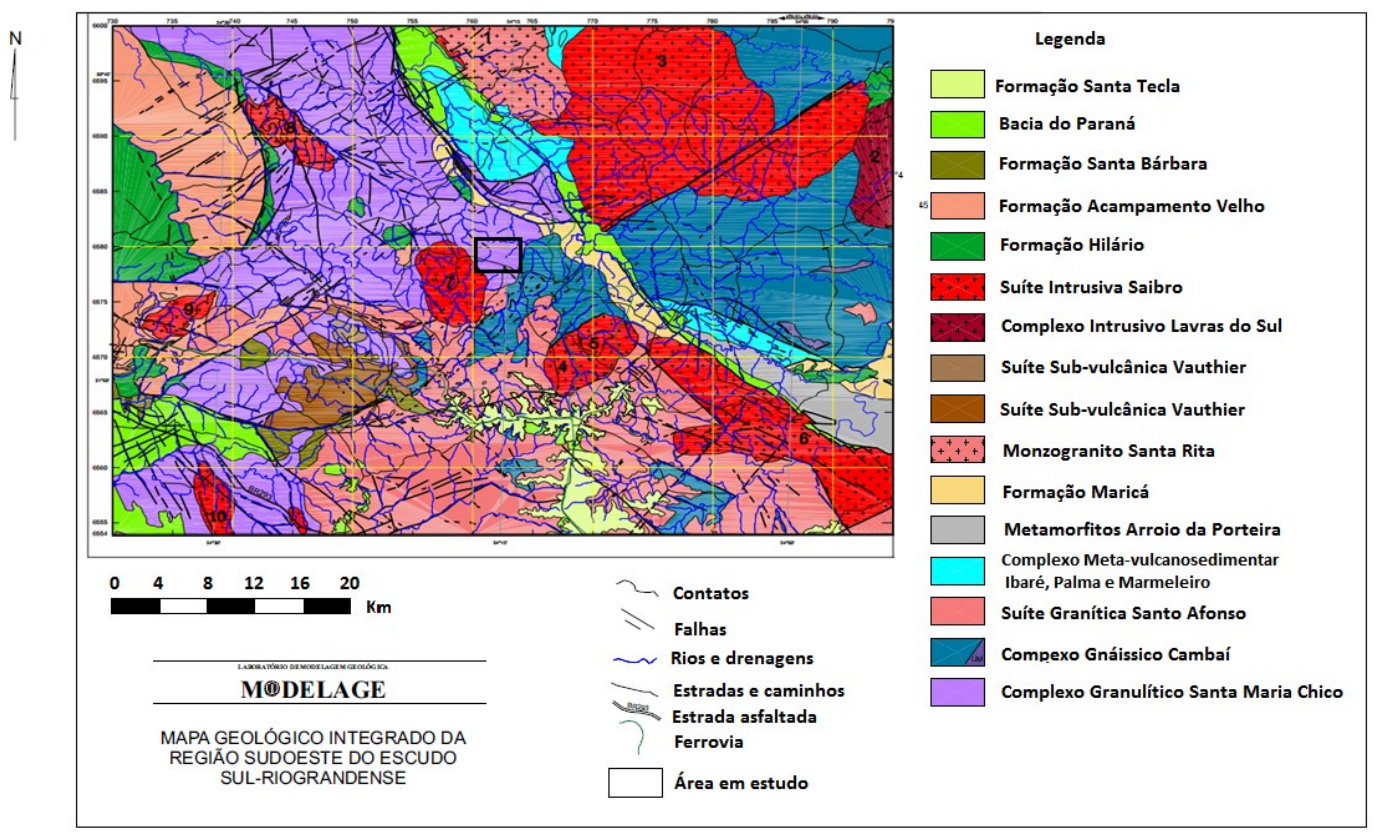

Figura 2: Mapa geológico da região sudoeste do Escudo Sul-Riograndense, onde em lilás se encontra o Complexo Granulitico Santa Maria Chico, e no quadrado central a área onde se encontram as alternativas locacionais para pilhas de estéril (modificado de Iglesias, 2000).

A mineralização consiste de um corpo intrusivo de Metacarbonatito do Proterozóico, embasado no Complexo Granulítico Santa Maria Chico descrito anteriormente. O Carbonatito Três Estradas é interpretado como tendo uma forma elíptica alongada com direção NE-SW e afloramentos ao longo de cerca de 2000 metros de comprimento, com uma largura média de 150m. No mapa da Figura 3 podemos identificar a predominância de gnaisse do Complexo Santa Maria Chico na área, esse gnaisse é responsável por grande parte do estéril que será retirado da mina, juntamente com o anfibolito e o metasienito, e também uma camada de solo e saprolito.

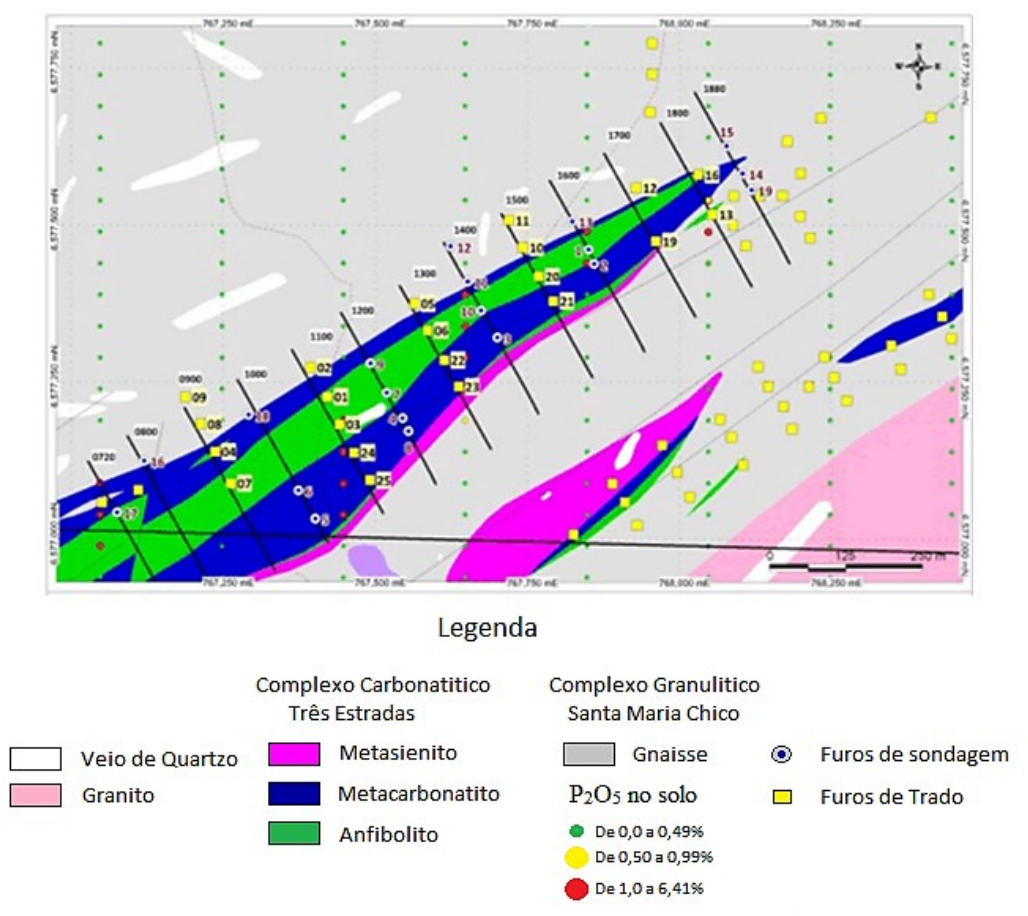




\subsubsection{Plano diretor realizado pela empresa para a disposição do estéril}

A partir de imagens de satélite foi realizado um plano diretor para a disposição do estéril, chegando assim à apresentação de quatro alternativas para pilhas de estéril (Figura 4), para o projeto, como segue:

- alternativa de pilha 1: situada a sul da futura cava da mina, abrange um área de 940 $\mathrm{m}^{2}$, com altura máxima de 90 metros, cota de elevação do topo de 410 metros, sendo capaz de estocar $31 \mathrm{Mm}^{3}$ de estéril;

- alternativa de pilha 2: situada à sudeste da futura cava da mina, abrange uma área de $840 \mathrm{~m}^{2}$, com uma altura máxima de 89 metros, cota de elevação do topo de 416 metros, apresentando a capacidade de estocar $31,6 \mathrm{Mm}^{3}$ de estéril;

- alternativa de pilha 3: situada à sudeste da futura cava da mina, abrange uma área de $990 \mathrm{~m}^{2}$, com uma altura máxima de 89 metros, cota de elevação do topo de 410 metros, com capacidade de estocar $31,7 \mathrm{Mm}^{3}$ de estéril;

- alternativa de pilha 4: situada a noroeste da futura cava da mina, abrange uma área de $580 \mathrm{~m}^{2}$, com uma altura máxima de 140 metros, cota de elevação do topo de 443 metros, com capacidade de estocar $31,2 \mathrm{Mm}^{3}$ de estéril.

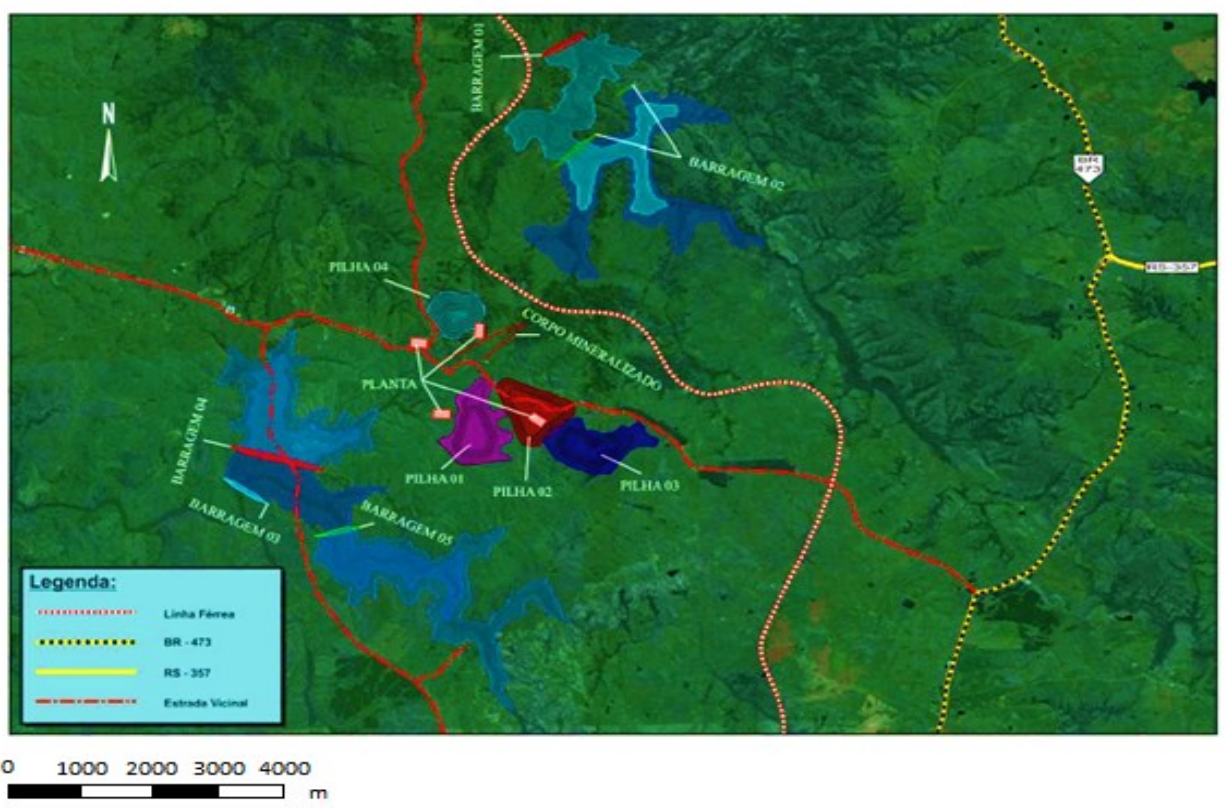

Figura 4: Plano diretor para a disposição do estéril e barragens de rejeito (fonte: Águia Resources, Volume II - Estudos Geotécnicose Hidrogeológicos).

\subsubsection{Pluviometria da área em estudo}

Segundo dados retirados de monitoramentos realizados pela estação meteorológica, instalada na proximidade da futura cava da mina, chegou-se a aproximadamente $1140 \mathrm{~mm}$ de precipitações no ano de 2013, ficando especificado no gráfico a seguir a distribuição das precipitações em cada estação do ano (Figura 5). 


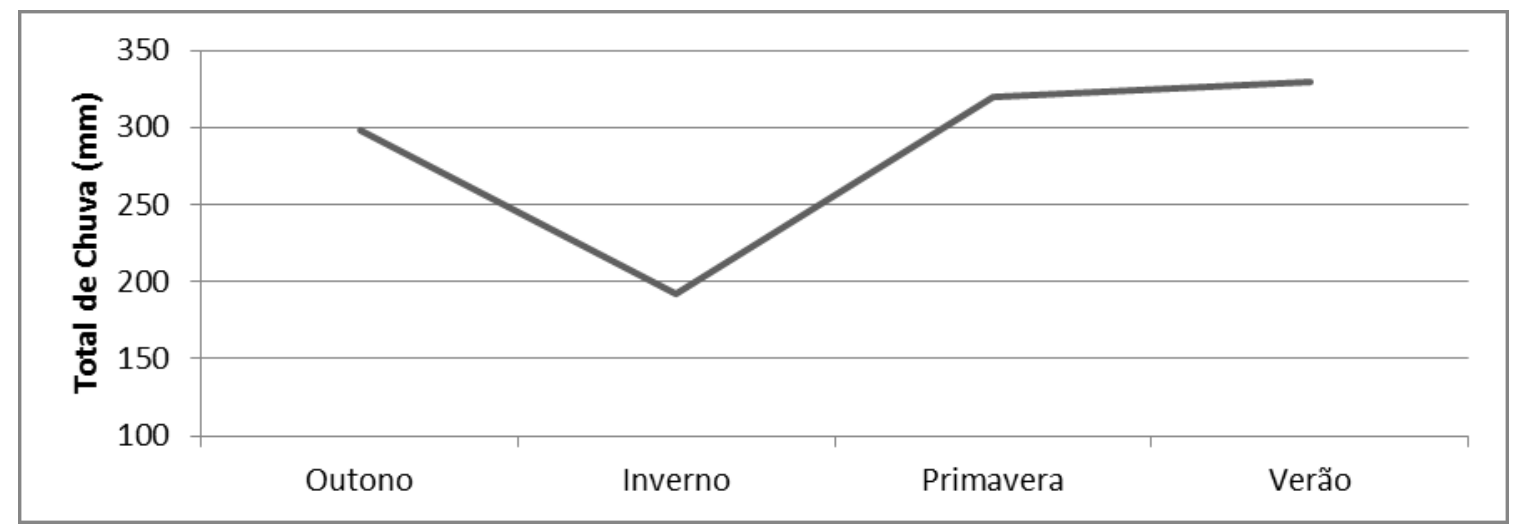

Figura 5: Gráfico de distribuição das precipitações em 2013 na área em estudo.

No gráfico acima se observa que a menor quantidade de precipitações ocorreu no inverno com 192 $\mathrm{mm}$ de chuva, e o máximo de precipitações ocorreu no verão com $330 \mathrm{~mm}$ de chuvas, sendo que esses dados foram retirados da estação meteorológica instalada no ano de 2013 na área do projeto.

\subsubsection{Hidrologia da área em estudo}

O município de Lavras do Sul se divide em duas regiões hidrográficas, sendo elas a Região Hidrográfica do Uruguai, e a Região Hidrográfica do Rio Camaquã, assim como se insere na do Rio Santa Maria. A área especifica do projeto se encontra inserida na Bacia Hidrográfica do Rio Santa Maria.

A Bacia Hidrográfica do Rio Santa Maria abrange uma área de $15.609,11 \mathrm{~km}^{2}$, entre as coordenadas geográficas $29^{\circ} 47^{\prime}$ a $31^{\circ} 36^{\prime}$ de latitude sul e $54^{\circ} 00^{\prime}$ a $55^{\circ} 32^{\prime}$ de longitude oeste, abrangendo os municípios de Bagé, Dom Pedrito, Lavras do Sul, Rosário do Sul, Santana do Livramento e São Gabriel.

Segundo a carta topográfica do IBGE - folha SH-21-Z-B-VI-4 em escala de 1:50.000, os principais cursos de água presentes nas proximidades da área do projeto são o Rio Jaguarí a Nordeste e o Arroio Taquarembó a Sul da futura cava da mina.

Nas atividades de campo pode-se observar que o fluxo natural de escoamento da água nas alternativas 1, 2 e 3, é no sentido para o Arroio Taquarembó (Figura 6), e na alternativa 4 no sentido para o Rio Jaguarí (Figura 7).

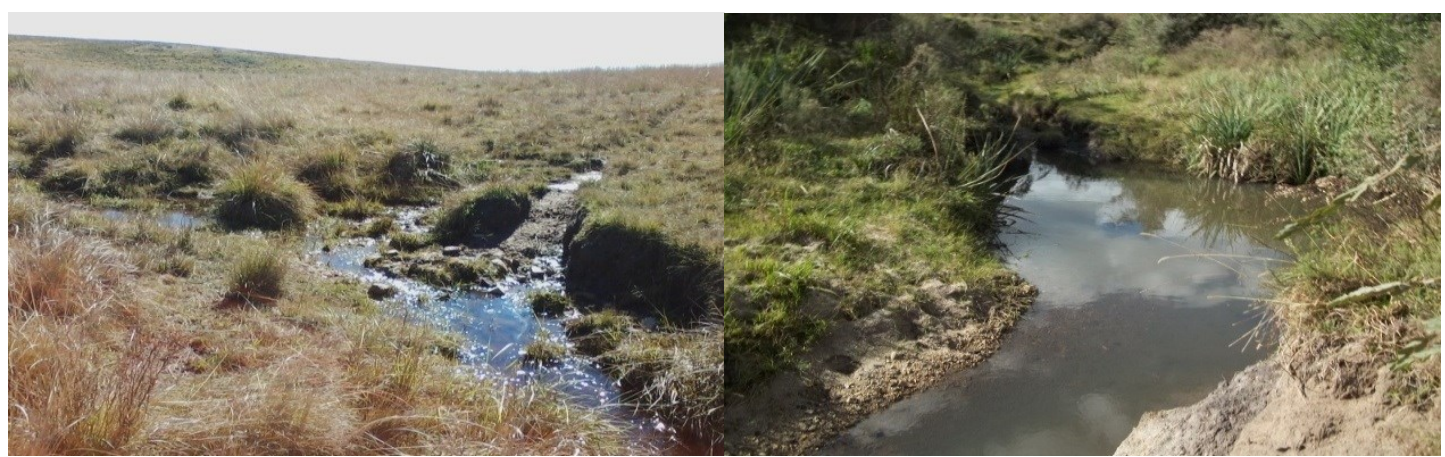

Figura 6: Detalhe dos fluxos de água presentes nas alternativas de pilha 1 e 3 respectivamente, escoando para o Arroio Taquarembó. 


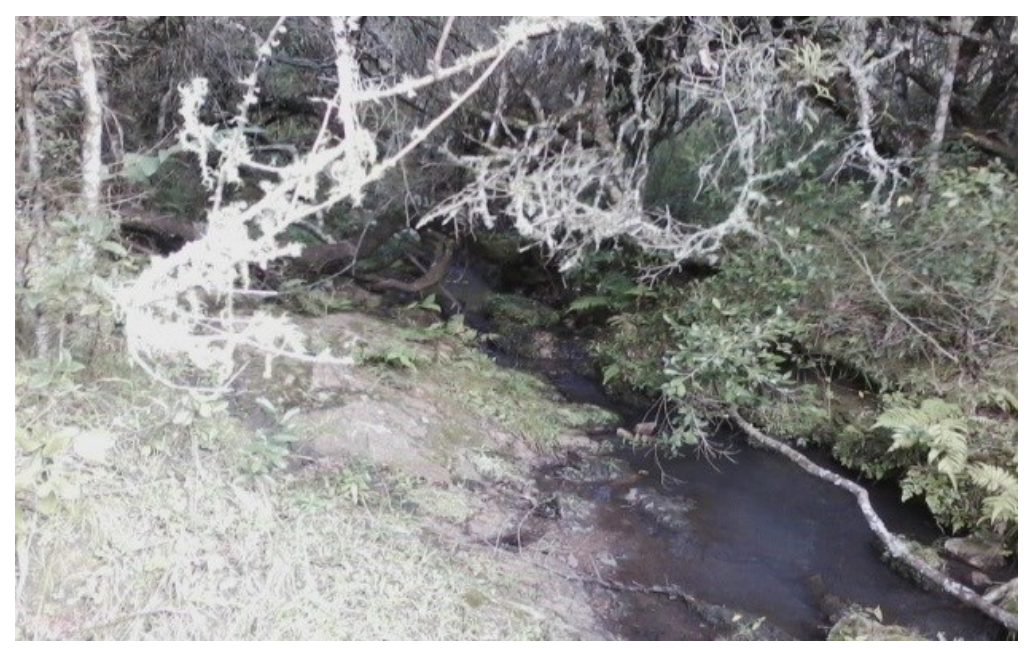

Figura 7: Detalhe do fluxo de água presente na alternativa 4, escoando para o Rio Jaguarí.

\subsubsection{Direção e intensidade dos ventos}

O conhecimento sobre a direção e intensidade dos ventos, é importante para o projeto de pilhas de estéril, pois podem carregar partículas para outras áreas, interferindo nos trabalhos, e também ocasionando acidentes pessoais e ambientais nas proximidades. Lavras do Sul é um município com certa intensidade de ventos, dados coletados na estação meteorológica da empresa Águia Metais mostram que a predominância da direção dos ventos varia de sudeste para leste (Figura 8), com velocidade média de aproximadamente $11 \mathrm{~m} / \mathrm{s}$.

Com esta direção dos ventos conhecida podemos salientar que as alternativas 1, 2 e 3, apresentam certo risco, pois se encontram a sudeste da futura cava da mina, podendo assim acarretar em carregamento de partículas das mesmas para a futura cava da mina, e também para algumas residências rurais presentes nas proximidades.

A alternativa 4 seria a que menos acarretaria riscos em relação à futura cava da mina, pois se localiza a noroeste da mesma, porém no que diz respeito a residências próximas, seria necessária a tomada de algumas medidas de mitigação. 


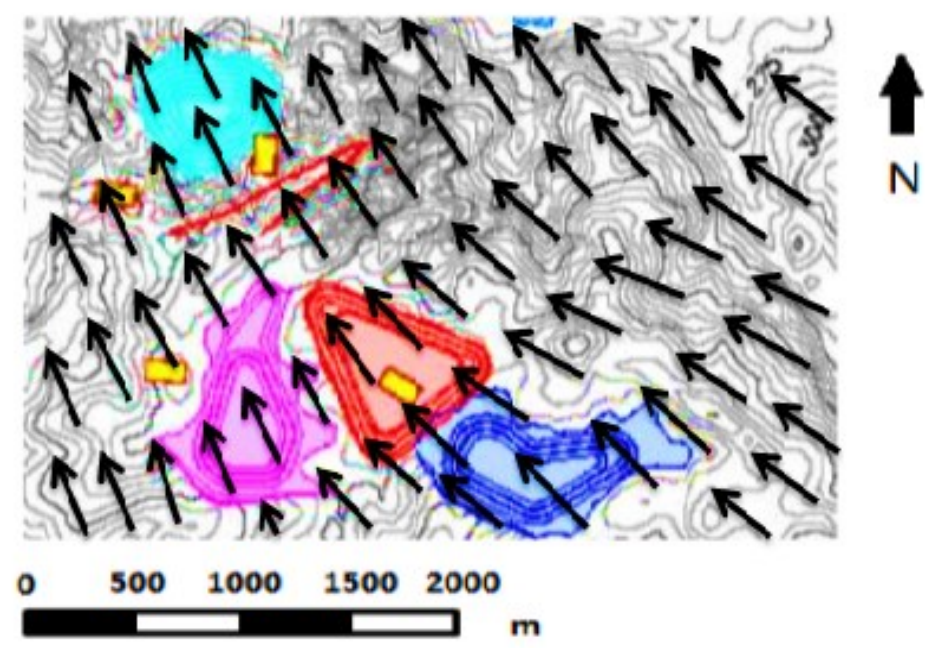

Alternativa de Pilha 1 Alternativa de Pilha 2 Alternativa de Pilha 3 Perfis de Caminhamento Alternativa de Pilha 4

Figura 8: Mapa de direções predominantes do vento em relação à localização das pilhas (modificado de Águia Metais, Volume II - Estudos Geotécnicos e Hidrogeológicos).

\subsubsection{Vegetação}

Segundo o IBGE, o Rio Grande do Sul está inserido em dois biomas, sendo eles o bioma Mata Atlântica e o bioma Pampa. A área em estudo esta situada no bioma Pampa, sendo que este é responsável por $2,07 \%$ da área total do país com $176.496 \mathrm{Km}^{2}$, com $46,26 \%$ do mesmo composto de vegetação de campo.

O município de Lavras do Sul, onde se localiza a área de estudo, está situado na mesorregião do Sudoeste do Rio Grande do Sul e também na microrregião da Campanha Meridional, que abrange também Garruchos, São Borja, Maçambará, Itaqui, Manoel Viana, São Francisco de Assis, Alegrete, Uruguaiana, Barra do Quaraí, Quaraí, Rosário do Sul, Santana do Livramento, São Gabriel, Santa Margarida do Sul, Dom Pedrito, Bagé, Hulha Negra e Aceguá (Chelotti, 2006).

Como dito anteriormente a área em estudo está situada no bioma Pampa, apresentando um relevo de planícies onduladas, com vegetação herbácea em estágio secundário em sua grande maioria, devido ao pastoreio realizado pela pecuária, setor de destaque da região (Figura 9). 


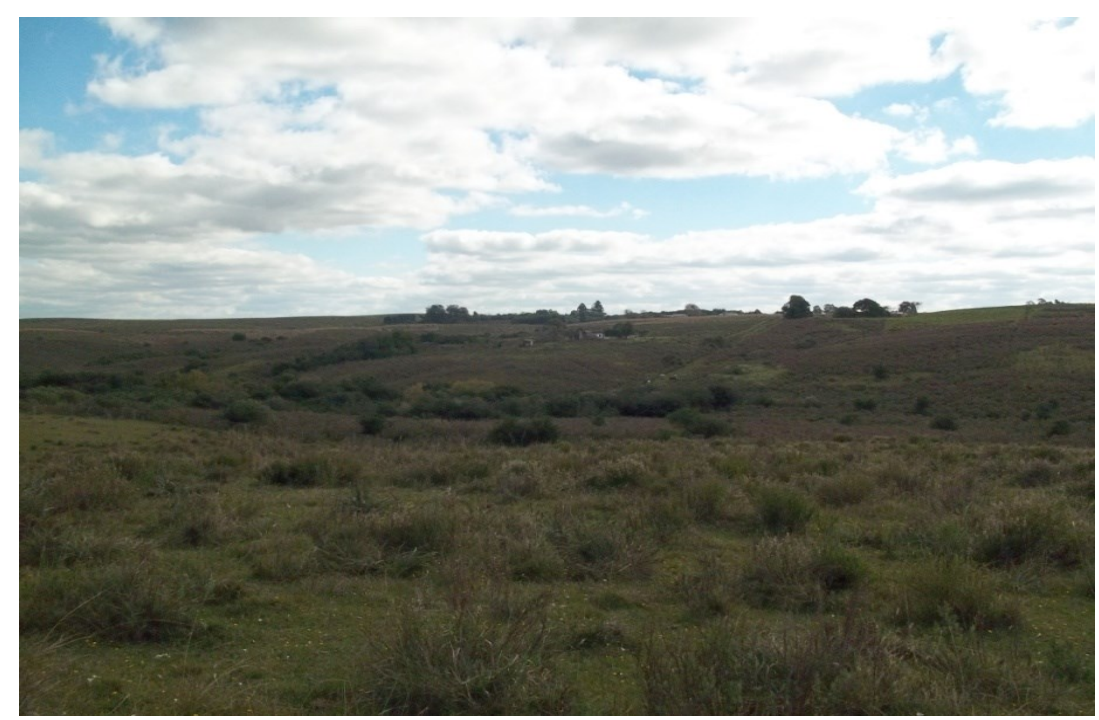

Figura 9: Imagem da vegetação campestre, predominante em grande parte da área.

\subsection{Metodologia de escolha da melhor alternativa locacional}

Para a obtenção dos dados da área foram utilizados relatórios feitos por uma empresa de consultoria ambiental, contratada pela empresa proprietária da área pesquisada, assim como relatórios e artigos publicados pela Águia Metais em seu site da Internet.

Durante os trabalhos do presente estudo foram realizados perfis longitudinais nos locais citados pelo plano diretor, nas alternativas locacionais para as pilhas de estéril (Figura 10), com o objetivo de coletar informações importantes, na escolha da melhor alternativa de locação da pilha e, desta forma, proceder a uma comparação juntamente com os dados obtidos do material bibliográfico, relatórios, etc.

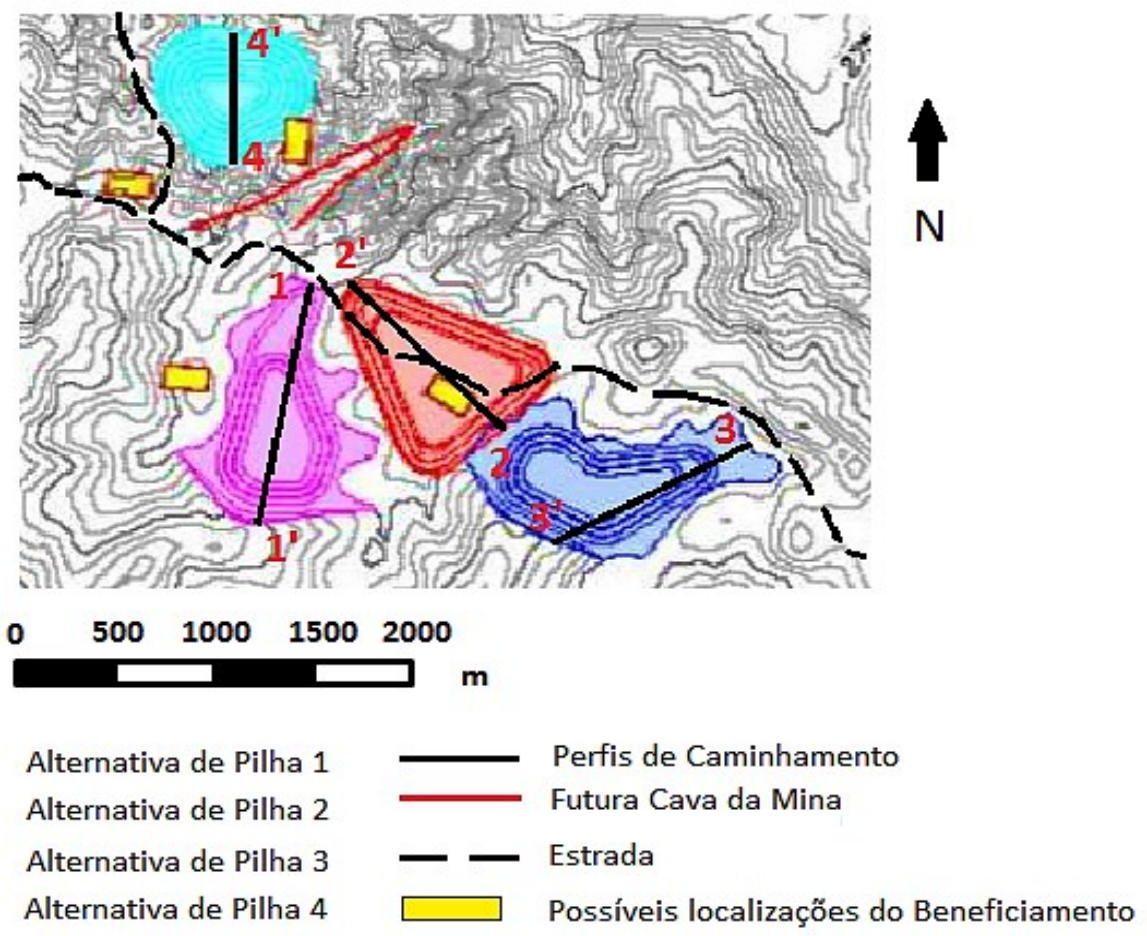

Figura10: Plano diretor das alternativas locacionais das pilhas de estéril e perfis de caminhamento realizados nos trabalhos de campo (modificado de Águia Resources Volume II - Estudos Geotécnicos e Hidrogeológicos). 
Os resultados destes levantamentos "in loco" estão mostrados nos perfis das Figuras 11 à 14 .

Alternativa de Pilha 1

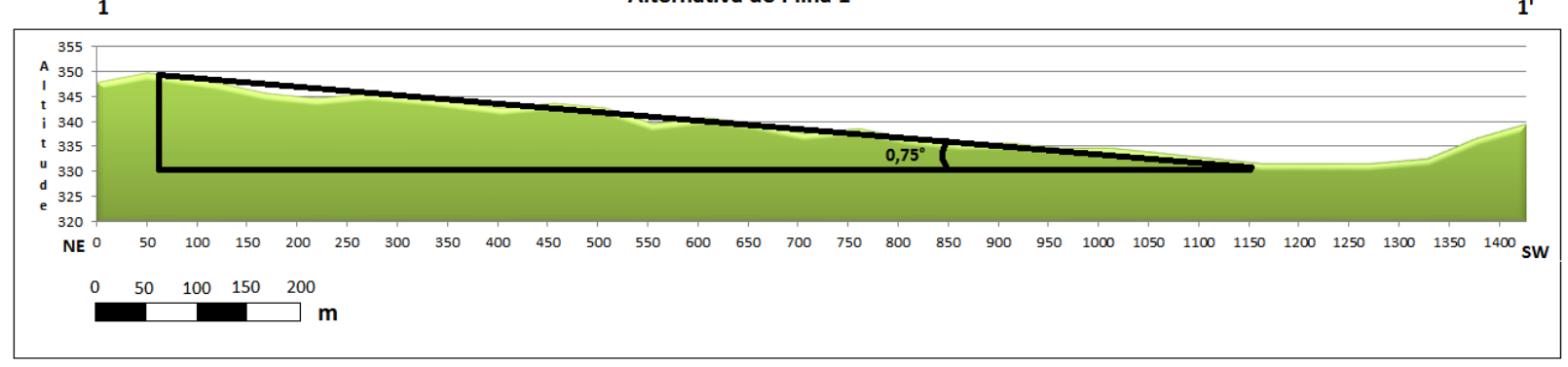

Figura 11: Perfil topográfico da alternativa de pilha 1.

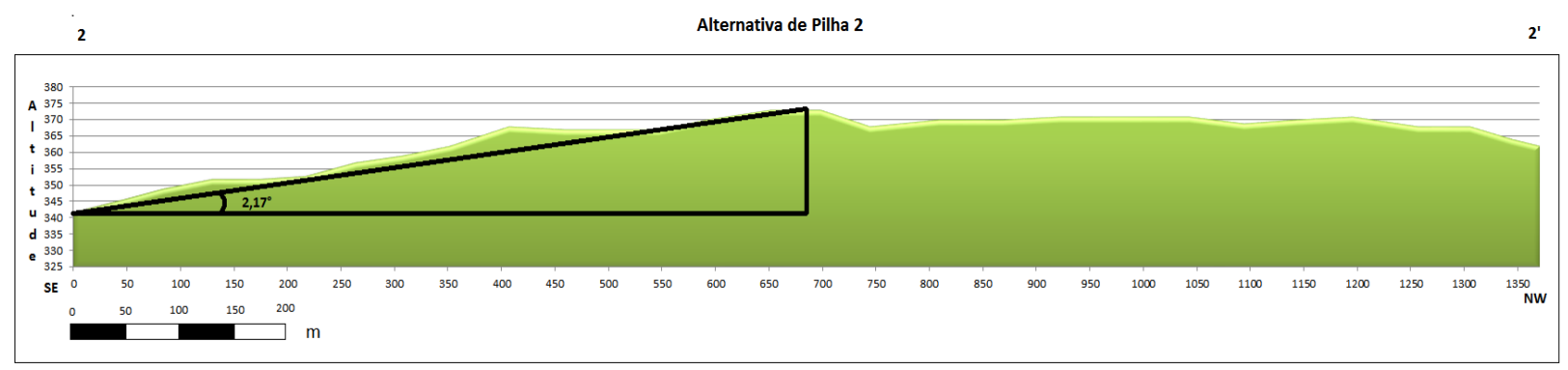

Figura12: Perfil topográfico da alternativa de pilha 2.

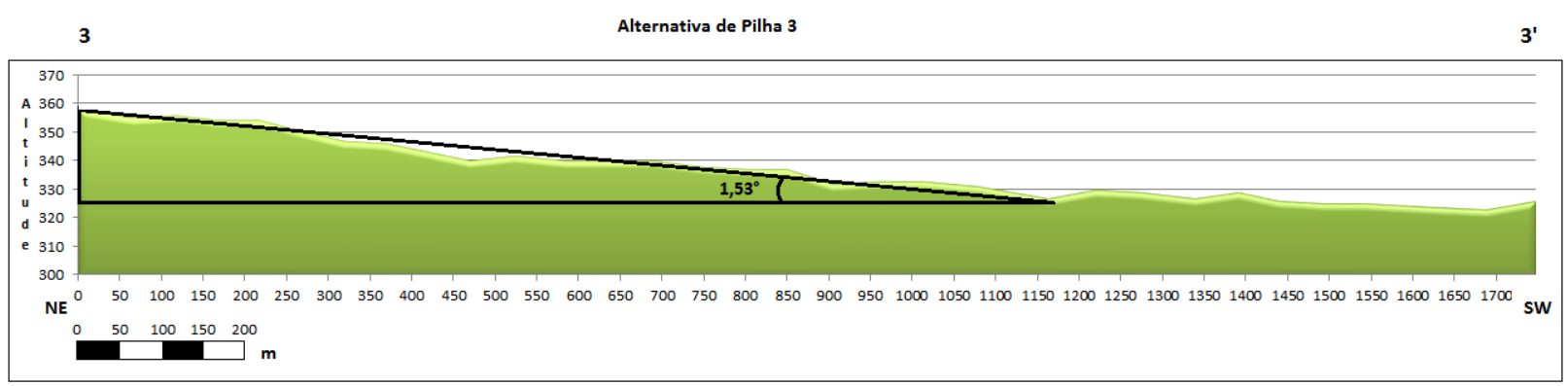

Figura13: Perfil topográfico da alternativa de pilha 3.

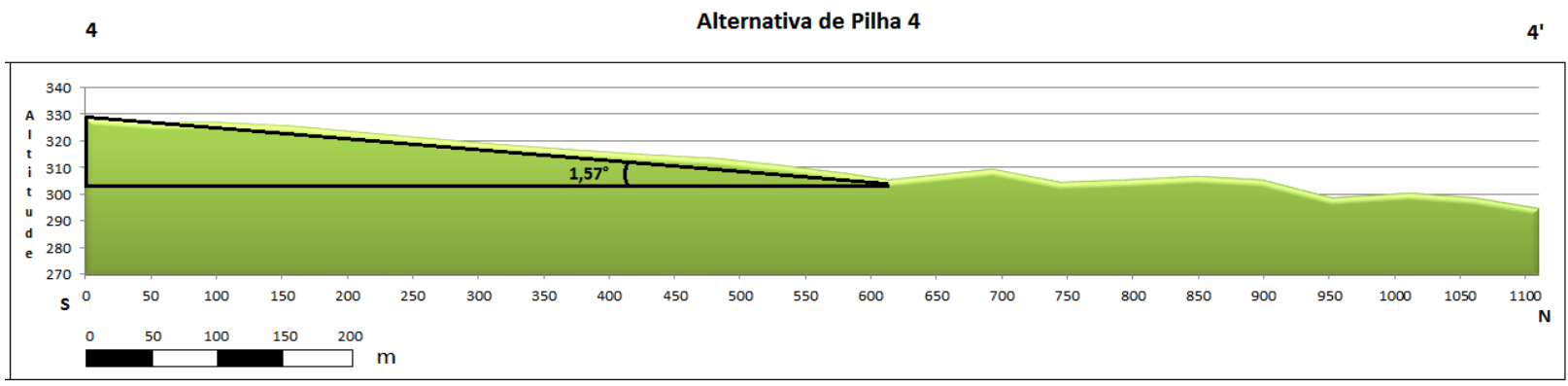

Figura14: Perfil topográfico da alternativa de pilha 4.

Com o tratamento dos dados levantados nos caminhamentos, observou-se que nenhuma alternativa ultrapassou os $18^{\circ}$, especificado na NBR 13029 como ângulo máximo para inclinação de talvegues, na disposição de estéril em pilhas. 
Utilizando-se das recomendações de caráter orientativo, presentes na NBR 13029 da ABNT, conforme especificado na revisão bibliográfica, considerada como um conjunto de recomendações para boas práticas de projeto de pilha de estéril, com forte caráter de "minimização dos impactos ao meio ambiente dentro dos padrões legais", chegou-se a uma atribuição de pesos para cada parâmetro citado na norma, além de outras características tomadas como importantes. A atribuição dos pesos está mostrada na Tabela 1. Após atribuídos os pesos de cada característica procedeu-se à comparação entre as alternativas de pilhas, no sentido de concluir qual alternativa apresentou menor somatório de fator de impacto ambiental.

Para a elaboração da tabela de atribuição dos pesos, os parâmetros foram classificados da seguinte maneira:

- 0: sem impacto ambiental;

- 1: baixo impacto ambiental;

- 2: médio impacto ambiental;

- 3: alto impacto ambiental.

Tabela 1: Atribuição de pesos para cada parâmetro observado nas alternativas das pilhas.

\begin{tabular}{|c|c|c|}
\hline \multicolumn{2}{|c|}{ Parâmetros } & $\begin{array}{c}\text { Fator de impacto } \\
\text { ambiental }\end{array}$ \\
\hline \multicolumn{2}{|c|}{ Dentro da própria cava da mina } & 0 \\
\hline \multirow{2}{*}{$\begin{array}{c}\text { Mais próximo } \\
\text { possível da cava }\end{array}$} & Próximo & 1 \\
\hline & Distante & 2 \\
\hline \multicolumn{2}{|c|}{ Áreas degradadas } & 1 \\
\hline \multicolumn{2}{|c|}{ Limites do empreendimento } & 2 \\
\hline \multicolumn{2}{|c|}{ Talvegues com inclinação maior de $18^{\circ}$} & 2 \\
\hline \multirow{2}{*}{$\begin{array}{l}\text { Áreas com } \\
\text { drenagens }\end{array}$} & Poucas drenagens & 1 \\
\hline & Muitas drenagens & 2 \\
\hline \multirow{2}{*}{$\begin{array}{l}\text { Áreas com } \\
\text { nascentes }\end{array}$} & Poucas nascentes & 1 \\
\hline & Muitas nascentes & 2 \\
\hline \multirow{3}{*}{$\begin{array}{l}\text { Áreas com } \\
\text { cursos de água }\end{array}$} & Inexistente & 0 \\
\hline & Fracos & 2 \\
\hline & Fortes & 3 \\
\hline \multirow{3}{*}{ Áreas com APP } & Nenhuma APP & 0 \\
\hline & Poucas APPs & 2 \\
\hline & Muitas APPs & 3 \\
\hline \multicolumn{2}{|c|}{$\begin{array}{c}\text { Áreas com terrenos instáveis, alagadiços e } \\
\text { inundados }\end{array}$} & 2 \\
\hline \multirow{3}{*}{$\begin{array}{l}\text { Áreas com } \\
\text { vegetação nativa } \\
\text { exuberante }\end{array}$} & Pouca Vegetação & 1 \\
\hline & Média Vegetação & 2 \\
\hline & Muita Vegetação & 3 \\
\hline \multicolumn{2}{|c|}{ Áreas com solo fértil } & 1 \\
\hline \multicolumn{2}{|c|}{ Áreas cortadas por estradas } & 1 \\
\hline \multicolumn{2}{|c|}{$\begin{array}{l}\text { Áreas com presença de rede de } \\
\text { transmissão de energia }\end{array}$} & 3 \\
\hline
\end{tabular}


Tabela 2: Comparação dos parâmetros para cada alternativa de pilha.

\begin{tabular}{|c|c|c|c|c|}
\hline Parâmetros & Pilha 1 & Pilha 2 & Pilha 3 & Pilha 4 \\
\hline $\begin{array}{c}\text { Dentro da própria cava da } \\
\text { mina }\end{array}$ & 0 & 0 & 0 & 0 \\
\hline $\begin{array}{l}\text { Mais próximo possível da } \\
\text { cava }\end{array}$ & 2 & 2 & 3 & 1 \\
\hline Áreas degradadas & 0 & 0 & 0 & 0 \\
\hline Limites do empreendimento & 2 & 2 & 2 & 0 \\
\hline $\begin{array}{l}\text { Talvegues com inclinação } \\
\text { maior de } 18^{\circ}\end{array}$ & 0 & 0 & 0 & 0 \\
\hline Áreas com drenagens & 2 & 1 & 2 & 1 \\
\hline Áreas com nascentes & 2 & 1 & 2 & 2 \\
\hline Áreas com cursos de água & 3 & 0 & 2 & 3 \\
\hline Áreas com APP & 3 & 2 & 3 & 3 \\
\hline $\begin{array}{l}\text { Áreas com terrenos } \\
\text { instáveis, alagadiços e } \\
\text { inundados }\end{array}$ & 2 & 2 & 0 & 0 \\
\hline $\begin{array}{c}\text { Áreas com vegetação nativa } \\
\text { exuberante }\end{array}$ & 1 & 2 & 2 & 3 \\
\hline Áreas com solo fértil & 1 & 1 & 1 & 1 \\
\hline Áreas cortadas por estradas & 0 & 1 & 0 & 0 \\
\hline $\begin{array}{c}\text { Áreas com presença de rede } \\
\text { de transmissão de energia } \\
\text { elétrica }\end{array}$ & 0 & 3 & 3 & 0 \\
\hline $\begin{array}{c}\text { SOMATÓRIO DE FATOR } \\
\text { DE IMPACTO } \\
\text { AMBIENTAL }\end{array}$ & 18 & 17 & 20 & 14 \\
\hline
\end{tabular}




\section{Resultados e discussão}

\subsection{Hierarquização}

A partir da análise quantitativa das situações envolvendo cada alternativa previamente proposta pela empresa idealizadora do plano diretor, obtém-se uma hierarquização das mesmas, de forma a classificar desde as com menores riscos de impactos ambientais até as com maiores riscos.

- alternativa de pilha 4: apresentando um somatório de fator de impacto ambiental 14, esta alternativa se apresenta, então, como a mais indicada para a escolha do local de disposição do estéril gerado na futura cava da mina, já que foi o valor mais baixo pontuado. Esta alternativa é também a que ocupará a menor área superficial, o que é um fator interessante, e a sua localização em relação à futura cava da mina é privilegiada, pois está localizada a noroeste da mesma e as direções predominantes dos ventos varia de sudeste para leste. Alguns fatores negativos desta alternativa, é que a mesma apresenta um curso de água que corta a área de norte para sul, com mata ciliar que o circunda, o que deve ser considerado como um fator complicador nos estudos de impactos ambientais;

- alternativa de pilha 2: esta alternativa apresentou um somatório de fator de impacto ambiental de 17, ficando assim como a segunda melhor alternativa. Esta apresenta alguns fatores positivos, como pouca presença de árvores, poucas nascentes e sem áreas alagadiças consideráveis, porém se encontra cortada pela principal estrada da área, a mesma que da acesso à futura cava da mina, provocando assim uma grande mobilização da infraestrutura local, e também tem a presença da rede principal de distribuição de energia elétrica da localidade. Outro fator crucial é que a mesma se encontra em um alto topográfico, complicando a sua conformação;

- alternativa de pilha 1: a alternativa de pilha 1 foi a terceira colocada no ranking das melhores alternativas do projeto, com um somatório de fator de impacto ambiental de 18. Os fatores que influenciaram negativamente esta alternativa foram a presença de uma grande área com terrenos instáveis e sujeitos a inundação, e também banhados, presença de um curso de água que corta toda a parte central da área, sem de mata ciliar, e também a presença de nascentes. Um fator positivo é que a área desta alternativa se encontra em um vale, onde seu preenchimento com estéril ficaria com conformidade boa, e também a pouca presença de mata nativa;

- alternativa de pilha 3: esta alternativa ficou em ultima colocada, com um somatório de fator de impacto ambiental 20. Alguns fatores que influenciaram negativamente foram a presença de um forte curso de água, que corta a área de Leste para Oeste, a presença de nascentes e drenagens, da rede principal de transmissão de energia elétrica, a proximidade de algumas residências rurais, e a distância em relação a futura cava da mina. Entre os fatores positivos estaria a conformação da pilha que se adequaria à área, pois a mesma se trata de um talvegue e seu preenchimento com material estéril se tornaria fácil, e outro fator positivo é a pouca presença de mata nativa, ficando em sua grande parte com vegetação gramínea que é de fácil compensação. 


\subsection{Proposição de medidas mitigadoras e compensatórias}

Como este projeto está vinculado aos trabalhos de pré-viabilidade da Águia Metais, propõe-se então algumas medidas mitigadoras, compensatórias e de recuperação que devem ser aprofundadas para a área escolhida pela empresa para receber a disposição do estéril gerado nos processos de desenvolvimento e operação da futura cava da mina.

\subsubsection{Caracterização dos resíduos para reaproveitamento}

Para um melhor planejamento da pilha é necessário que o estéril seja caracterizado, de acordo com as normas existentes. Essa caracterização tem como principal objetivo garantir que a disposição dos resíduos sólidos referentes a fase de implantação e operação do projeto seja controlada respeitando características próprias dos resíduos como ângulo de repouso natural, coesão, dentre outras: aumentar a eficiência da recuperação da pilha, indicando quais medidas devem ser tomadas para preparar o material afim de ser revegetada a área e por fim minimizar os impactos ambientais, através de tratamento e disposição adequados dos resíduos sólidos.

\subsubsection{Controle nos níveis de ruídos}

A área se encontra longe de centros urbanos, o que diminui o risco com ruídos para pessoas, a menos para os funcionários envolvidos diretamente nas áreas afetadas, para isso é necessário o uso de EPI's, e controle da manutenção periódica das máquinas utilizadas. Também a implantação de uma cortina vegetal no entorno da pilha ajuda a conter os ruídos ocasionados pelo movimento das máquinas.

\subsubsection{Controle da qualidade do ar}

É inevitável a geração de poeira onde se tem deslocamento de equipamentos pesados, para isso é necessário que se mantenham as vias de acesso conservadas umedecidas com a utilização de caminhões pipa. Também é notável a contaminação do ar por gases oriundos da queima de combustível fóssil, para isso deve-se que as maquinas e equipamentos estejam bem regulados e lubrificados.

Outra medida importante é a implantação de uma cortina vegetal para conter o deslocamento de partículas transportadas pelo vento da pilha para a futura cava da mina. A alternativa de pilha 4 não apresenta muito risco para os trabalhos da cava, pois as direções predominantes dos ventos variam de Sudeste para Leste, e esta alternativa se encontra a Noroeste da futura cava da mina. Porém esta alternativa apresenta uma estrada secundária a Leste, exigindo assim uma cortina vegetal para conter o carreamento de partículas.

\subsubsection{Revegetação}

Logo após concluídas as bancadas, a revegetação pode começar a ser realizada com a plantação de gramíneas nativas, ou exóticas que se adaptem a região. E, após o término da disposição do estéril na pilha, deve-se realizar uma revegetação com árvores nativas. A própria cortina vegetal citada anteriormente vai auxiliar na minimização de vários impactos.

\subsubsection{Drenagem}

A alternativa 4 apresenta um curso de água e, para que isso não interfira no comportamento da pilha e também na qualidade da água ao redor, é necessário que se tome algumas medidas como, instalação de um sistema de drenagem interno, superficial e periférico para escoamento da água, para 
escoamento do curso de água presente na área deve ser construído um dreno de fundo, tudo isso atendendo as exigências presentes em normas técnicas. A jusante da pilha deve ser instalada uma caixa de decantação que esteja dentro das normas técnicas vigentes.

Outra medida importante para a gestão dos recursos hídricos da área é o monitoramento da água subterrânea com a utilização de piezômetros (poços de monitoramento) a montante e a jusante da pilha seguindo normas técnicas existentes, para com isso acompanhar possíveis alterações na qualidade da água. É importante ressaltar que como premissa do projeto inicial da Águia Metais, o estéril é considerado sem potencial para geração de água ácida ou "drenagem ácida", porém sabe-se que sempre podem ocorrer alterações químicas na água ocasionadas por ações mal tomadas.

Para um melhor controle das alterações que possam ocorrer nos recursos hídricos locais, é interessante o monitoramento da qualidade da água nos principais cursos de água a jusante da pilha, como o Rio Jaguarí para a alternativa de pilha 4.

\subsubsection{Controle da estabilidade dos taludes}

Este item é de suma importância para o planejamento ambiental das pilhas de estéril, pois um deslizamento de um talude pode acarretar prejuízos econômicos e ambientais. Para que isso não ocorra, é necessário que o estéril proveniente do desenvolvimento e das operações da mina seja devidamente caracterizado, para que, ações de disposição do mesmo sejam tomadas com intuito de atender certas características como coesão, ângulo de repouso natural do estéril, conforme normas técnicas existentes. A Figura 15 demonstra o perfil da Pilha 4, com os parâmetros geométricos e de acordo com as dimensões totais previstas para esta pilha, confirmando os parâmetros que a norma NBR 13029 estipula.

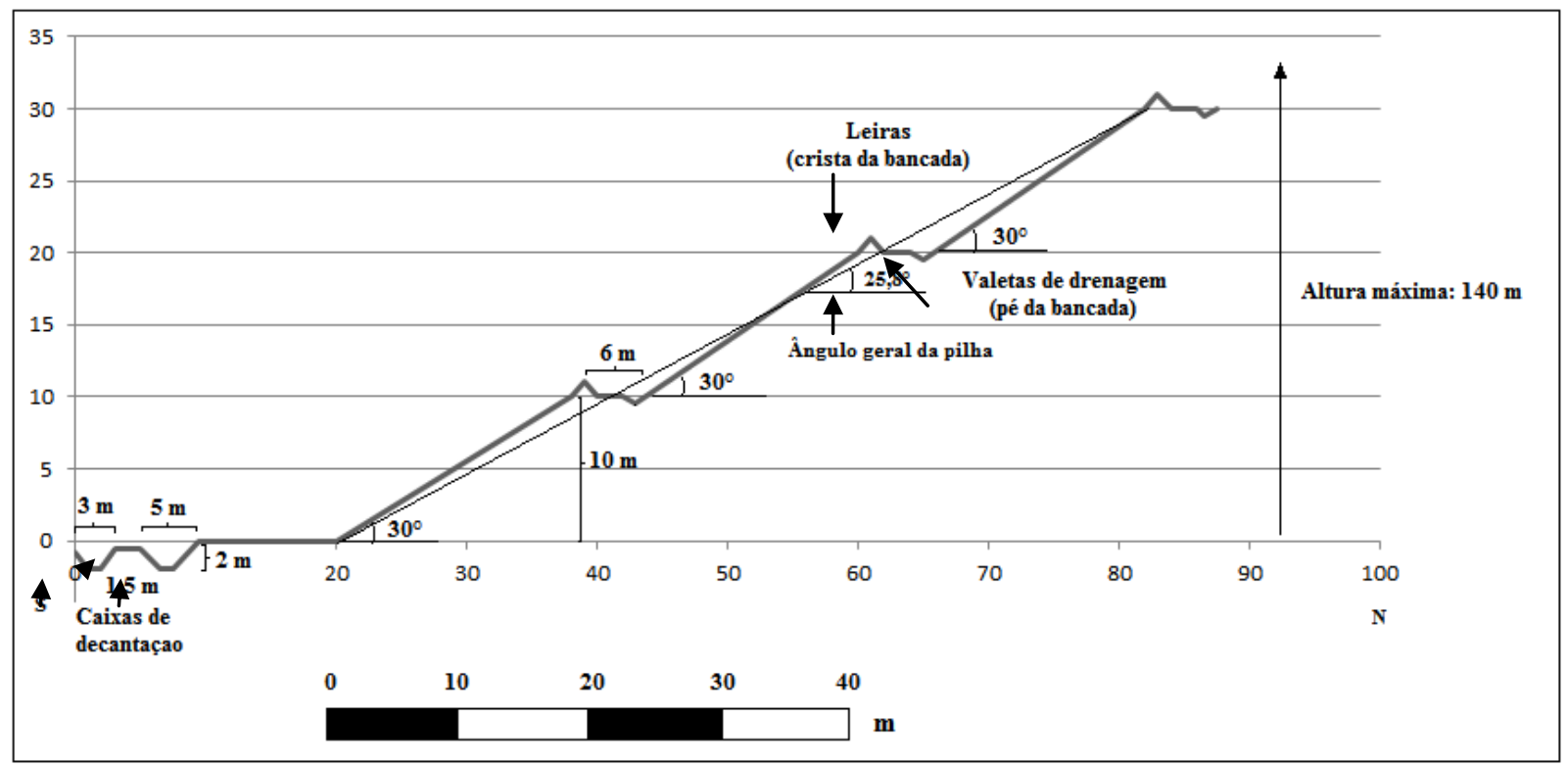

Figura 15: Perfil demonstrando a geometria da pilha 4.

\subsection{Matriz de impacto ambiental simplificada}


Tabela 3: Matriz de impacto ambiental simplificada.

\begin{tabular}{c|c|c} 
Impacto & Medida Mitigadora & Medida Compensatória \\
\hline $\begin{array}{c}\text { Geração de resíduos } \\
\text { estéreis }\end{array}$ & $\begin{array}{c}\text { Caracterização do material estéril } \\
\text { Elevãão nos níveis de } \\
\text { ruído }\end{array}$ & $\begin{array}{c}\text { Reaproveitamento do } \\
\text { material }\end{array}$ \\
\hline $\begin{array}{c}\text { Geração de poeñão de máquinas e } \\
\text { equipamentos } \\
\text { gases tóxicos }\end{array}$ & $\begin{array}{c}\text { Implantação de cortina vegetal } \\
\text { Implantação de cortina vegetal. } \\
\text { Manutenção das máquinas e } \\
\text { equipamentos. }\end{array}$ & - \\
\hline Impacto visual & Revegetação e cortina vegetal & Revegetação \\
\hline $\begin{array}{c}\text { Alterações na qualidade } \\
\text { das águas superficiais }\end{array}$ & $\begin{array}{c}\text { Implantação de veletas de drenagem } \\
\text { nas crista e pés dos taludes e caixa } \\
\text { de decantação à jusante da pilha }\end{array}$ & Monitoramento \\
\hline Ruptura de taludes & $\begin{array}{c}\text { Revegetação } \\
\text { Ângulo de talude inferior ao ângulo } \\
\text { de repouso natural do material e } \\
\text { fatores de segurança dentro das } \\
\text { normas. }\end{array}$ & Revegetação \\
\hline
\end{tabular}

\section{Conclusões e recomendações}

Com a realização deste trabalho, chegou-se a uma hierarquização das alternativas de pilha de estéril para o Projeto Três Estradas, ficando a alternativa número 4 como a melhor, seguindo recomendações presentes nas normas do DNPM e da ABNT. Algumas medidas devem ser tomadas por parte da Águia Metais, tais como a caracterização do estéril, chegando a parâmetros como ângulo de repouso natural, coesão, coeficiente de atrito interno que permitam realizar simulações do "Fs" (fator de segurança) da estabilidade dos taludes e confirmar que o ângulo projetado de " $30^{\circ}$ " é suficientemente seguro.

Considera-se que os objetivos propostos no trabalho foram atingidos, sendo que o tipo de metodologia adotada se mostrou adequada ao tipo de trabalho, ou seja, o planejamento ambiental de pilhas de estéril, principalmente na fase de pré-viabilidade de um projeto de mineração. A metodologia adotada foi baseada nos princípios das "matrizes ambientais quantitativas", onde se aplicam critérios de avaliação de parâmetros adequados ao tipo de análise ou empreendimento, as quais vêm sendo atualmente objeto de muitos estudos e publicações nos sentido de auxiliar a decisão no contexto técnico e ambiental. Desta forma, a aplicação para decisão sobre locação de pilhas de estéril, conforme sugerido neste trabalho, pode ser considerada com caráter inovador, neste contexto.

\section{Agradecimentos}

Agradeço a Águia Metais Ltda, pela colaboração e por permitir a realização deste trabalho utilizando dados do projeto, pois sem estes a realização do mesmo não se tornaria possível. Agradeço aos Geólogos Lucas Mendes Galinari e Alfredo Rossetto Nunes por todo auxilio prestado e incentivo. 
Aos colegas Evandro Gomes e Dartanhan Valcarenghi, pelos incentivos e contribuições, enfim a todos os professores e colegas da UNIPAMPA que de certa forma contribuíram para a realização deste trabalho. E agradeço a minha família pelo apoio dado.

\section{Referências}

ÁGUIA RESOURCES, Estudos preliminares geotécnicos, de recursos hídricos e ambientais para o projeto Fosfato Três Estradas, Volume II - Estudos Geotécnicos e Hidrogeológicos, 26 p, (2012).

CHELOTTI. M.C. Produção desigual do espaço e dinâmica regional da agropecuária na Campanha Gaúcha (Brasil). Observatórium. Revista Eletrônica de Geografia. V. 2. N6. P36-7. 2006.

IGLESIAS, C.M.F. Análise integrada de dados geológicos e estruturais para a prospecção de ouro na região de Torquato Severo (RS). Programa de Pós-Graduação em Engenharia de Minas, Metalúrgica e de Materiais - PPGEM - Porto Alegre (2000).

IBGE, Instituto Brasileiro de Geografia e Estatística. Carta topográfica - Folha Coxilha do tabuleiro (SH-21-Z-BVI-4) em escala 1:50.000 (1980).

IBGE. Instituto Brasileiro de Geografia e Estatística. Informações Municipais. Disponivel em http://cidades.ibge.gov.br/xtras/perfil.php?lang=\&codmun=431150 - Acesso em Agosto de 2014.

MONTAÑO, M; RANIERI, V. E. L. ; SOUZA, M. P. Sistemas de Informação Geográfica Aplicados à Análise Ambiental: Subsídios à Gestão Ambiental Municipal. In: III Simpósio Internacional de Qualidade Ambiental - Gestão Ambiental Urbana e Industrial, (2002).

NBR 13029 (2006) - Elaboração e apresentação de projeto de disposição de estéril, em pilha, em mineração, Associação Brasileira de Normas Técnicas - ABNT, 8 p, (2006).

NRM 19 - Disposição de Estéril, Rejeitos e Produtos, Departamento Nacional de Produção Mineral DNPM.

SÁNCHEZ, L.E. Livro Avaliação de impacto ambiental: conceitos e métodos, ed. Oficina de Textos São Paulo, 495 p, (2008).

SANTOS, R.F. Livro Planejamento Ambiental: teoria e prática, ed. Oficina de Textos - São Paulo, 184 p (2004). 